\title{
Shock attenuation in shoes compared to barefoot: a systematic review
}

\author{
Alycia Fong Yan ${ }^{1 *}$, Claire Hiller ${ }^{2}$, Peter Sinclair ${ }^{1}$, Richard Smith ${ }^{1}$ \\ From 3rd Congress of the International Foot and Ankle Biomechanics Community \\ Sydney, Australia. 11-13 April 2012
}

\section{Background}

The debate over the advantages and disadvantages of barefoot versus shod running has gained momentum recently $[1,2]$ with the retail market aiming to mimic the motion of the foot during barefoot gait[3]. The aim of this study was to conduct a systematic review of articles that compared shock attenuation in the shod condition to barefoot during weight bearing activity in healthy individuals.

\section{Materials and methods}

The major databases were searched for the following keywords: barefoot, foot, feet, boot*, shoe*, impact, shock, pressure, force, viscoelastic, and insert. Articles were screened with inclusion and exclusion criteria set $a$ priori. Articles were grouped according to shoe type and where possible, a meta-analysis was used.

\section{Results}

Thirty-eight articles were found with 27 articles examining athletic shoes compared to barefoot. For running, footwear attenuated loading rate and tibial acceleration (Table 1). In contrast, the use of shoes increased vertical ground reaction forces (vGRF) during running (Table 1) and walking when measured at the impact transient. Results varied significantly in favour of the shod or barefoot condition depending on whether data was collected at the impact transient or the peak. Thirteen articles did not report the footfall technique, while two studies reported variable technique.

Table 1 Pooled effect of bare feet vs. athletic footwear during running (+'ve: attenuated in BF, -'ve: attenuated in shod)

\begin{tabular}{|c|c|c|c|c|c|}
\hline Variable & $\begin{array}{l}\text { Time of } \\
\text { Collection }\end{array}$ & \# of Studies & $n$ & $\begin{array}{l}\text { Mean } \\
\text { Difference } \\
{[95 \% \mathrm{Cl}]}\end{array}$ & P Value \\
\hline \multirow[t]{2}{*}{$\begin{array}{l}\text { Vertical Ground } \\
\text { Reaction Force }\end{array}$} & $\begin{array}{l}\text { Impact } \\
\text { Transient }\end{array}$ & De Wit et al 2000, Divert et al 2005, Esnault 1985, Lieberman et al 2010 & 108 & $\begin{array}{l}0.22[0.20 \\
0.23]\end{array}$ & $<0.00001$ \\
\hline & $\begin{array}{l}\text { Peak } \\
\text { Force }\end{array}$ & $\begin{array}{l}\text { Alcantara et al 1996, Braunstein et al 2010, Dickinson et al 1986, Fong et al 2007, } \\
\text { Kerrigan et al 2009, Serrao \& Amadio 2001, Squadrone \& Gallozzi 2009,Stockton \& } \\
\text { Dyson } 1998\end{array}$ & 128 & $\begin{array}{l}-0.03[-0.07 \\
0.01]\end{array}$ & 0.19 \\
\hline \multirow[t]{2}{*}{ Loading Rate } & $\begin{array}{l}\text { Impact } \\
\text { Transient }\end{array}$ & De Wit 2000, Lieberman 2010 & 72 & $\begin{array}{l}-3.56[-4.10 \\
-3.02]^{*}\end{array}$ & $<0.00001$ \\
\hline & $\begin{array}{l}\text { Peak } \\
\text { Force }\end{array}$ & Alcantara 1996, Serrao \& Amadio 2001 & 11 & $\begin{array}{l}-0.59[-2.52 \\
1.35]^{*}\end{array}$ & 0.55 \\
\hline $\begin{array}{l}\text { Tibial } \\
\text { Acceleration }\end{array}$ & $\begin{array}{l}\text { Peak } \\
\text { Force }\end{array}$ & Alcantara et al 1996, McNair \& Marshall 1994 & 18 & $\begin{array}{l}-3.19[-4.35 \\
-2.03]^{*}\end{array}$ & $<0.00001$ \\
\hline
\end{tabular}

*Standardised Mean Difference [95\% Cl]

\footnotetext{
* Correspondence: afon6063@uni.sydney.edu.au

${ }^{1}$ Faculty of Health Science, The University of Sydney, Sydney, NSW, 2041,

Australia

Full list of author information is available at the end of the article
} 


\section{Conclusions}

Evidence suggests the shock absorbing properties of athletic footwear are effective during jump landings. Results varied significantly in favour of the shod or barefoot condition depending on whether data was collected at the impact transient or the peak. Footfall technique appears to have a significant effect on vertical ground reaction force. Activity-specific designs for footwear should take into account the region of the shoe which absorbs the initial impact. Attention should be given to develop consistent protocols for examining shock attenuation in footwear research.

\section{Author details}

'Faculty of Health Science, The University of Sydney, Sydney, NSW, 2041, Australia. ${ }^{2}$ Discipline of Physiotherapy, The University of Sydney, Sydney, NSW, 2041, Australia.

Published: 10 April 2012

\section{References}

1. Lieberman DE, Venkadesan M, Werbel WA, Daoud Al, Dandrea S, Davis IS, Mangeni RO, Pitsiladis Y: Foot strike patterns and collision forces in habitually barefoot versus shod runners. Nature 2010, 463:531-535.

2. Jenkins DW, Cauthon DJ: Barefoot running claims and controversies. J Am Podiatr Med Assoc 2011, 101:231-246.

3. Squadrone R, Gallozzi C: Biomechanical and physiological comparison of barefoot and two shod conditions in experiences barefoot runners. $J$ Sports Med Phys Fitness 2009, 49:6-13.

\section{Submit your next manuscript to BioMed Central} and take full advantage of:

- Convenient online submission

- Thorough peer review

- No space constraints or color figure charges

- Immediate publication on acceptance

- Inclusion in PubMed, CAS, Scopus and Google Scholar

- Research which is freely available for redistribution

Submit your manuscript at www.biomedcentral.com/submit 